\title{
Reported Speech in Greek Tragedy
}

\author{
JAMES T. CLARK
}

This article examines reported direct speech embedded in narrative sections of Greek tragedy, analyzing the content of reported speeches, their metrical form, and the descriptions of their sound. Reported direct speech is revealed to be considerably restrained, even when it occurs in highly emotional contexts. This restraint is interesting, given the prevalence of non-linguistic cries in tragedy, and it is brought into particular relief by comparison with the descriptions of violent utterances that often precede or follow sections of direct speech. There is a discernible, though inconsistent, trend towards the loosening of this restraint in later Euripides.

\section{Introduction}

The importance of sound to Greek tragedy has been emphasized by several recent studies that highlight the prevalence of cries, shrieks, and other non-linguistic utterances. ${ }^{1}$ In this paper I argue that, given this context, direct speech embedded within messenger speeches and other non-choral narratives in Greek tragedy is significantly restrained, that the speeches might accurately be described as "spoken" or "shouted" (their volume is sometimes referred to), but not "shrieked" or "wailed." The way some scholars have attributed violent effects to these speeches suggests that this is not a self-evident point, and it is interesting that the speeches are so restrained given that they often purport to be the reported speech of characters in highly emotional states. ${ }^{2}$

1. See Nooter (2017) on Aeschylus and, in her introduction, on tragedy in general, and Weiss (2017) on the relationship between inarticulate noise and song in tragic laments. Gurd (2016) discusses sound in Greek literature in general, but frequently touches on tragedy. For extant tragedies all Greek is quoted from the relevant Oxford Classical Texts: Page (1972) for Aeschylus, Lloyd-Jones and Wilson (1992) for Sophocles, and Diggle (1981-1994) for Euripides. Sophocles's Eurypylus is quoted from Radt (1999). I standardize the orthography so that all texts use quotation marks to indicate the reported speech and the iota subscript instead of adscript. The translations are adapted from the relevant Loeb versions: Sommerstein (2008) for Aeschylus, Lloyd-Jones (1994-1996) for Sophocles, and Kovacs (1994-2002) for Euripides.

2. De Jong (1991) 134 is correct that direct speech is not used exclusively at moments of high emotion, but there are still many such instances, and it is on these that my discussion focuses. 
The bulk of this study consists of a detailed examination of selected passages, considering the speeches' metrical form, their diction and phrasing, and the words used to describe them. But at times I rely on quantitative data, such as the frequency of a certain effect, and so I need to define a corpus from which to draw this data. My corpus consists of the quoted speeches within the passages identified as narrative in Appendix 1 of Margaret Dickin's study of messenger speeches. ${ }^{3}$ There is a full list of the quoted speeches in my corpus in the appendix to this article. To the list obtained from Dickin I add one speech each from Euripides's Cyclops and Rhesus (Dickin's appendix ignores both plays), and several from fragmentary plays where the context appears to be narrative.

There are two advantages to using Dickin's list. First, using a pre-defined set of passages mitigates the risk of selection bias when identifying trends (i.e., I cannot be tempted to find reasons for excluding passages that render uninteresting results). Secondly, Dickin takes a broad view of what constitutes a narrative passage, including some prologues and other extended narratives in addition to speeches by reporting figures. For my purposes - a close examination of a small aspect embedded within a larger narrative-I do not consider it important whether the larger narrative is classified as a messenger speech, ${ }^{4}$ especially as recent scholarship has argued convincingly that messengers, far from being merely functional devices, are individualized characters with a personal reaction to the events they report. This last point has been brought out most clearly by De Jong's application of narratological theory to Euripidean messenger speeches. ${ }^{5}$ De Jong's conclusions have implications for this study: the speeches are reported by narrators who, due to their status as characters, are not omniscient, and who choose how they tell the story and what they include. This means we cannot treat the reported speeches as a complete and exact record of what was said off-stage, as two examples show: in Euripides's Orestes the Phrygian does

3. Dickin (2009) 155-73. Like Dickin, I exclude choral passages since they would be significantly different from non-choral in terms of both performance and interpretative considerations.

4. In any case, such a classification would not be definitive. De Jong (1991) 179-80 excludes speeches where the speaker is a major character, but Barrett (2002) 97 argues that at Soph. Trach. 749-806 Hyllus's report is "virtually indistinguishable from those of figures explicitly identified as messengers." Perris (2011) expands the definition even further, including, for example, Talthybius's speech at Eur. Tro. $1123-55$ as a report narrative.

5. De Jong (1991), especially her second chapter. Heath (1987) 153-57 briefly makes a similar case, though without applying narratology. Both are in part responding to Barlow (2008), first edition published in 1971, who emphasizes instead the features of the Euripidean messenger that are unobtrusive, while acknowledging that by their nature they must be subjective. See also Barrett (2002) 14-22. 
not report the cries we have already heard Helen utter (at 1296 and 1301), but another cry instead; at Euripides's Heraclidae 839-40 the Messenger combines two separate speeches, one addressed to the Athenians, the other to the Argives. ${ }^{6}$ I will return to these considerations in my final section, which is concerned with the reasons for and effects of restraint in reported direct speech, but first I need to demonstrate that this restraint exists.

\section{Restraint in Reported Speech}

Before examining any passage in detail, I survey the verbs of speaking used to introduce or cap quoted speeches, since it is principally through these verbs that direct speech is characterized. ${ }^{7}$ In a discussion of the verbs of speaking in Homer's Iliad, De Jong draws on speech act theory to distinguish between verbs which indicate only a locutionary act (e.g., eĩ̄ov, which refers only to the act of speaking), and others which also indicate an illocutionary act ("the making of a

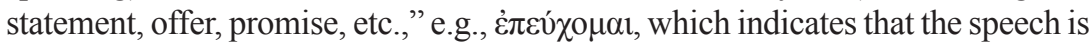
a boast). ${ }^{8}$ I adopt this framework for the current study but—given my particular focus - extend it to include the extra dimension of sound. Over three quarters of the passages in my corpus are introduced by verbs of speaking that offer no significant indications of how the speeches sounded. This group includes both

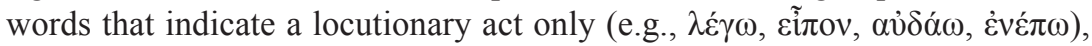
which account for over half the passages in my corpus, and also those where some illocutionary force is present (e.g., $\left.\dot{\alpha} \mu \varepsilon \dot{\beta} \beta \mu_{\alpha 1,} \varepsilon \tilde{\chi} \chi 0 \mu \alpha 1, \kappa \varepsilon \lambda \varepsilon v ́ \omega\right)$, which

6. I owe both examples to De Jong (1991) 134-36.

7. Sometimes other parts of speech contribute to the description of quoted speeches, but it is rare that they give the impression of harsh or violent speech. Bers (1997) 75 says that Hippolytus

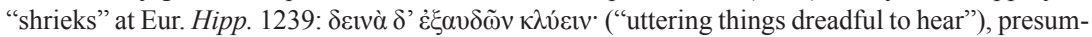
ably because of $\delta \varepsilon v \alpha \grave{\alpha} \kappa \lambda v \varepsilon \varepsilon v$. But parallels of this phrasing from other tragedies show that this need not mean that the sound itself is terrible, but rather its import. At Soph. OC 141 the Chorus say that

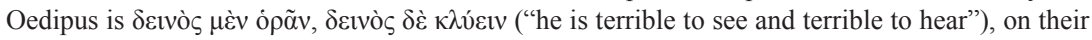
first encounter with him. It is unlikely that this is a description of the sound of Oedipus's speech at 138-39; it is probably reflective of their alarm. Similarly Castor's reaction to Orestes's words at

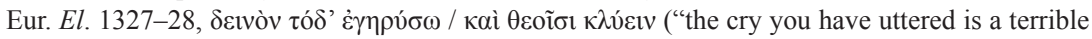
one even for the gods to hear"), seems to be a reaction to their content (Orestes asking Electra to mourn for him as if he were already dead) rather than to their sound. Kaimio (1977) 186 lists places where $\delta \varepsilon t v o ́ \varsigma$ seems to refer to the sound but says of Eur. Hipp. 1239 "the main reference may be to the substance of Hippolytus' cry."

8. De Jong (2004) 200-3 uses the framework described in Levinson (1983) 236, from which the description of the illocutionary act that I quote is taken. This framework has a third element, the perlocutionary act, which is the effect of a speech on the addressee, but this is not expressed by the verb of speaking. 
account for almost a quarter of passages. The other major group, which also is found in almost a quarter of passages, are verbs indicative of high volume. These words are mainly only locutionary ( $\beta$ oó $\omega$ and its cognates is most common), though occasionally some illocutionary force is detectable, such as with $\kappa \alpha \lambda \varepsilon \dot{\varepsilon} \omega .{ }^{9}$ Such verbs do tell us something about the sound, but only in a limited way: a shout need not sound harsh or emotionally charged. ${ }^{10}$

From this brief survey it is clear that while there is a broad range of verbs of speaking used, they rarely characterize the sound of the speech as anything more than loud. In fact, there are only three plays in my entire corpus that contain introductions to direct speech that I consider expressive of the sound: Euripides's Phoenissae and Orestes, and - more doubtfully—Sophocles's Eurypylus. It seems that, consciously or not, the tragedians avoided expressive descriptions of quoted speeches. This avoidance is even more striking when contrasted with the vibrant descriptions that are often given to narrated utterances. Two examples should help to make the point. In Aeschylus's Persians the Messenger describes the Greeks as they prepared for battle:

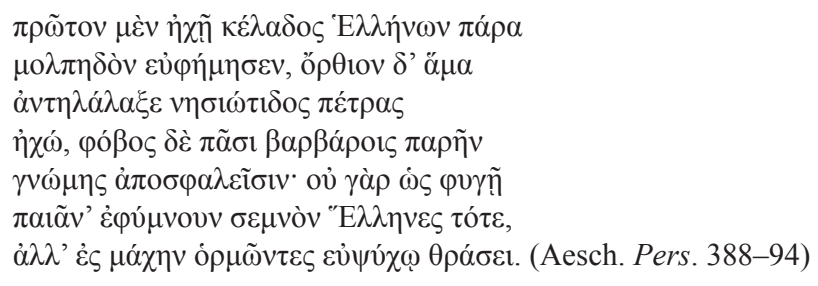

First of all there rang out loudly a joyful sound of song from the Greeks, and simultaneously the echo of it resounded back shrilly from the cliffs of the island. All we Easterners were terrified, because we had been deceived in our expectation: the Greeks were now raising the holy paean-song, not with a view to taking flight, but in the act of moving out to battle, with cheerful confidence.

9. The precise implications of these words are not always clear, and I cannot always be certain that, e.g., $\kappa \alpha \lambda \varepsilon \dot{\varepsilon} \omega$ is indicative of volume rather than acting as an equivalent to $\kappa \varepsilon \lambda \varepsilon v ́ \omega$. But a different classification for some words would not distort the general picture. I include in this group

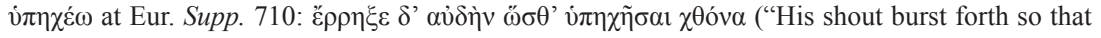
the land echoed with it"). While De Jong (1991) 145 is right to point out the unusual formulation and how it contributes to the presentation of Theseus as "an almost superhuman commander," it characterizes only the volume of Theseus's speech.

10. Note that I am interested specifically in speeches that sound emotionally charged (e.g., shrieks, wails, howls), not speeches that merely have emotional content. 
The sounds are well characterized in this passage, with nine words used in their description. The verbs of speaking initially used here for the sound and its echo $(\varepsilon \dot{v} \varphi \eta \mu \varepsilon \dot{\varepsilon} \omega$ and $\dot{\alpha} v \tau \alpha \lambda \alpha \lambda \dot{\alpha} \zeta \omega)$ are certainly more unusual than those generally used for direct speech, but particularly effective are ö $\rho \theta 1$ ov ("shrilly"), which describes the pitch of the sound, something that never happens with quoted speech, and $\mu \mathrm{o} \lambda \pi \eta \delta$ òv, which is a hapax and explicitly characterizes the Greeks' sound ( $\kappa \dot{\varepsilon} \lambda \alpha \delta o \varsigma)$ as song-like. ${ }^{11}$ Contrast this with the description just eight lines later (402), when the Messenger quotes a Greek shout, describing it as $\pi \mathrm{o} \lambda \lambda \dot{\eta} v$ ßoฑ́v ("a great cry"), an unusually simple description for Aeschylus. ${ }^{12}$ This pattern of extensive characterization of described speech, followed by minimal characterization of quoted speech is also found in Sophocles's Trachiniae:

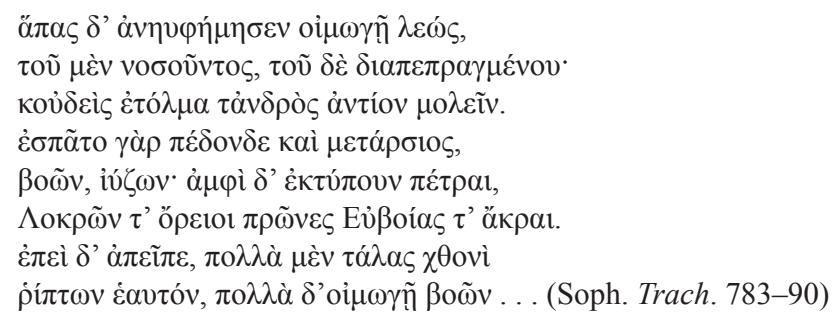

And the whole people cried out with awe at the sickness of the one and the undoing of the other; but no one dared to come near the man. For the pain dragged him downwards and upwards, shouting and screaming; and the rocks around resounded, the mountain promontories of Locri and the Euboean peaks. But when he gave over, hurling himself often to the ground, wretched, and uttering many loud cries ...

This passage is from Hyllus's narrative of Heracles's agonies after donning the poisoned robe. Here too there is a detailed description of a cry and its echo: note, for example, the first verb of speaking, $\dot{\alpha} v \varepsilon v \varphi \eta \mu \varepsilon \dot{\varepsilon} \omega$, which according to Easterling's gloss, "sent up an awe-stricken wail," clearly characterizes the sound as something beyond normal speech. ${ }^{13}$ Heracles's cries are described with ßoó $\omega$, which often introduces the speeches in my corpus, but also with iv́ $\zeta$, which

11. Several scholars have noted the abundant description of the sound here: see Garvie (2009) 191; Gurd (2013) 126-8 and (2016) 65-66; Nooter (2017) 72-73.

12. Kaimio (1977) 173 observes: "simple characterizations of sound with one qualifying adjective or adverb are remarkably rare in Aeschylus."

13. Easterling (1982) 170. This verb is not in the Sophoclean manuscripts (which are clearly

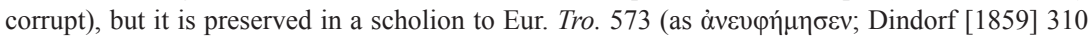
corrected to $\alpha \dot{v} \vartheta \varphi \eta \dot{\mu} \eta \sigma \varepsilon v)$. 
never does, and which seems to denote a cry of pain or grief. ${ }^{14}$ Twice the verb of speaking is qualified by the dative of manner oip $\omega \gamma \tilde{n}$, which indicates a wailing sound. Just seven lines after this passage Hyllus quotes Heracles's words, but the description of the speech there is much simpler (796): $\kappa \alpha \lambda \varepsilon \tilde{i}$ ("he called").

The impression that tragedians tend to avoid using direct speech for particularly violent or emotional utterances is strengthened by a number of passages where such utterances stop just before the quoted speech. In these passages we often find an expressive verb of speaking and a mild one in quick succession. Scholars have interpreted some of these passages as if both verbs applied to the direct speech, and the ambiguities of Greek mean this cannot always be ruled out entirely, but I think in every case it is preferable for us to understand that the speaker ends their more expressive utterance before the switch is made to direct speech. I begin with an uncontroversial example: at Euripides's Hippolytus 1181 the Messenger

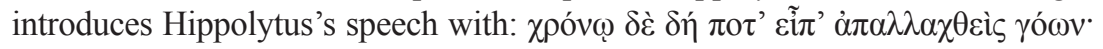
("When some time had passed, he ceased his lamenting and said"). In this instance the shift from lamentation to speech is explicit: Hippolytus had been lamenting, he stopped, then he spoke. This pattern repeats elsewhere, but it is not always so clear. At Euripides's Heracles 935 the Messenger introduces Heracles's speech

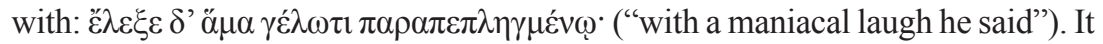
is possible that this phrasing indicates that Heracles's speech was peppered with laughter, but I follow Victor Bers in concluding that a single laugh just before Heracles speaks is the likeliest interpretation, especially since there is no indication of laughter in the quoted text. ${ }^{15}$ Less than sixty lines later the same effect is achieved by linking the expressive verb to the verb of speaking by кaí (981): o $\delta$ '

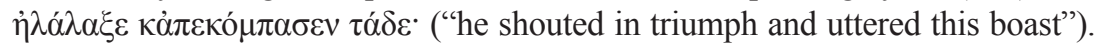
The difficulty of taking $\eta^{\lambda} \lambda \alpha^{\lambda} \lambda \alpha \xi \varepsilon$ as transitive with $\tau \dot{\alpha} \delta \varepsilon$ as its object makes a sequential, rather than simultaneous, reading of the verbs preferable here. ${ }^{16} \mathrm{~A}$ similar formulation is used to introduce Alcestis's appeal to her marriage bed:

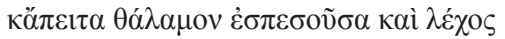

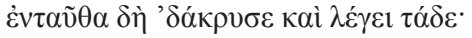

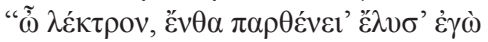

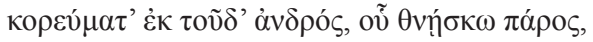

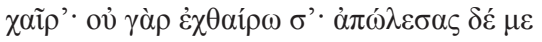

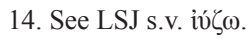

15. Bers (1997) 80 says: "the speech is either prefaced with a single insane laugh, or we are meant to imagine continuous outbreaks." But in his footnote he adds: " $\alpha \mu \alpha$ is more likely to suggest a single event, cf. $\ddot{\alpha} \mu$ ' $\tilde{\eta} \rho . " ”$

16. Elsewhere, $\dot{\alpha} \lambda \alpha \lambda \dot{\alpha} \zeta \omega$ is rarely transitive: the other four Euripidean uses are intransitive, and in tragedy it is only used transitively once (Soph. Ant. 133), where the object, víknv, can be taken as a cognate accusative: "shout the shout of victory." See LSJ s.v. $\dot{\alpha} \lambda \alpha \lambda \dot{\alpha} \zeta \omega$. 


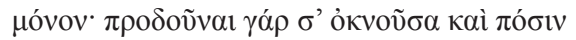

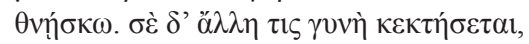

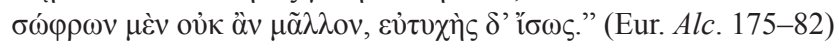

Then she entered the bedchamber. Here at last she wept and said, "O marriage bed, where I yielded up my virginity to my husband, the man for whose sake I am now dying, farewell! I do not hate you, although it is you alone that cause my death: it is because I shrank from abandoning you and my husband that I now die. Some other woman will possess you, luckier, perhaps, than I but not more virtuous."

In his translation Conacher interprets the two verbs as simultaneous: "Then, finally, she did weep as she cried out." ${ }^{\prime 17}$ This reading is appealing because it is natural to conceive of weeping as an event which continues for some time. It might seem, then, that this constitutes a counter-example to the general pattern

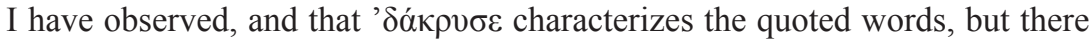
are two points against this view. First, the combination of an aorist (' $\delta \alpha \dot{\kappa} \kappa v \sigma \varepsilon$ ) with a historic present $(\lambda \dot{\varepsilon} \gamma \varepsilon 1)$ could tell against such a reading. The traditional explanation of historic presents is that they make the narrative more vivid, ${ }^{18}$ but recently several scholars have sought to demonstrate that they have more to do with marking different points in a narrative or different narrative modes.$^{19}$ If this is correct, and $\lambda \dot{\varepsilon} \gamma \varepsilon \mathrm{l}$ here marks both a narrative peak and a switch to a more immediate mode of presentation, then the connection between the two verbs is

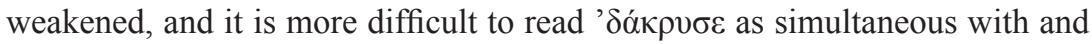
characterizing the quoted speech..$^{20}$ The second point is that even if ' $\delta$ ók $\rho v \sigma \varepsilon$ were simultaneous with the speech, it does not necessarily characterize its sound.

17. Conacher (1988) 77.

18. See, e.g., De Jong (1991) 39. Rijksbaron (2006) 129 disagrees: ““vividness' is to my mind not a central notion in connection with the historic present."

19. Van Emde Boas et al. (2019) 430-31 identify two uses for the historic present. First, "it is used occasionally to highlight decisive or crucial events in a narrative;" secondly it is used "to 'punctuate' a narrative, dividing it up into separate sections by highlighting each new step." See also Rijksbaron (2002) 22-25. Allan (2009) 192-95 proposes a similar schema but splits the first use into two: one to mark the narrative peak (to which he assigns $\lambda \dot{\varepsilon} \gamma \varepsilon 1$ at Eur. Alc. 176), the other to mark particularly dramatic events. Earlier in the same paper Allan (2009) 174 suggests that the use of historic presents is one factor which identifies the "immediate diegetic mode," where "the narrator acts as if there is no spatial and temporal difference between the experience and the reporting of the events."

20. A more comprehensive study of this point would be welcome. I note that a historic present is used alongside a past tense to indicate simultaneous events at Eur. Hec. 574 and Phoen. 1473-77, but in both cases the verbs have different subjects so could more easily receive different narrative presentation. Euripides did not refrain from using two historic presents when describing simultaneous events (e.g., Eur. Heracl. 20), so perhaps we should note his avoidance of this here. However, 
It is possible to shed tears silently, and Kovacs notes that in tragedy $\delta \alpha \dot{\kappa} \rho-$ words often seem to refer to inaudible weeping. ${ }^{21}$

There is nothing in the quoted words themselves to suggest that they were spoken simultaneously with sobbing, although there are some indications of Alcestis's emotional state. The address to the marriage bed is in itself suggestive of high emotion, and the number of short phrases and the enjambment in three consecutive lines is indicative of agitation. But this is far removed from the utterances full of interjections that are common in tragedy, and Markantonatos talks about Alcestis's “admirable composure" here. ${ }^{22}$ There is a similar passage in Sophocles's Trachiniae, where the Nurse describes Deianeira's appeal to her bridal bed:

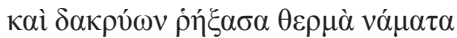

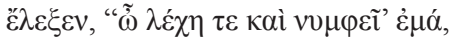

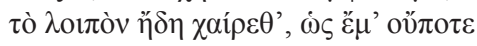

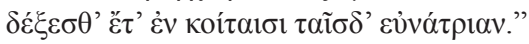

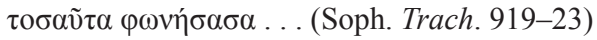

Hot streams of tears burst from her eyes, and she said, "O my bridal bed, farewell now for ever, since you will never again receive me to lie upon this couch.” Having said so much ...

The phrase $\delta \alpha \kappa \rho v ́ \omega \nu ~ \rho ́ \eta ́ \xi \alpha \sigma \alpha \theta \varepsilon \rho \mu \alpha ̀ ~ v \alpha ́ \mu \alpha \tau \alpha$ could be interpreted as Deianeira beginning to weep, in which case it would suggest that Deianeira is still in tears as she speaks. However, this phrase might be simply a periphrasis for

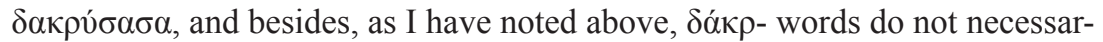
ily indicate audible sobbing. There is nothing in the text here that suggests the sound of Deianeira's words was impacted by her tears. Both the introductory

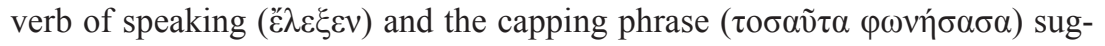
gest nothing more than speech, and the quoted words themselves are even less expressive than those in Alcestis.

Two passages from the Messenger's speech in Sophocles's Antigone are introduced in a similar way:

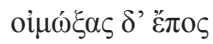

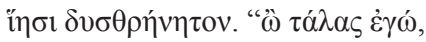

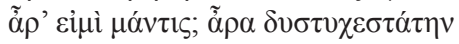

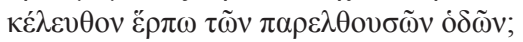

I would stress that the functions of the historic present on which my argument here is based are not beyond doubt: De Jong (1991) 41 makes a case for some of its occurrences being simply variation.

21. Kovacs (2014) 62n19: "No audible sounds are to be inferred from $\delta \alpha ́ \kappa \rho-$ words, as at [Soph.] Ant. 527, 803, or at Tr[ach.] 38."

22. Markantonatos (2013) 48. 


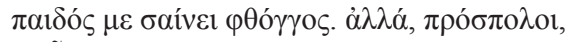

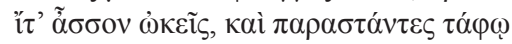

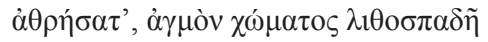

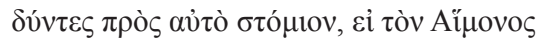

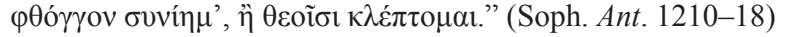

And having groaned he uttered a lamenting word: "O my unhappy self, am I a prophet? Am I travelling on the saddest path of all the ways I have come in the past? I recognize my son's voice! Come, attendants, swiftly come near, stand by the tomb, and look, entering the gap made by the tearing away of the stones, to see whether I know the voice of Haemon, or the gods deceive me!

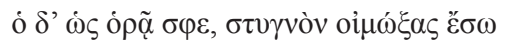

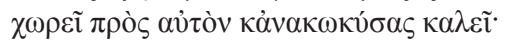

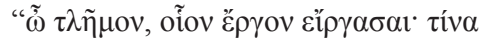

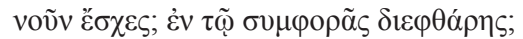

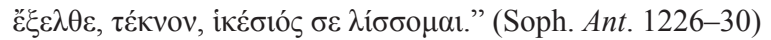

But when Creon saw him, he gave a dreadful groan and came inside towards him and having raised a wail called on him: "Wretch, what a thing you have done! What was in your mind? At what point of disaster did you lose your reason? Come out, my son, I beg you as a suppliant!”

In both passages the direct speech is introduced with the same type of formulation - aorist participle and historic present main verb — but scholars' interpretations of these introductions are very different. In the first passage the participle and verb

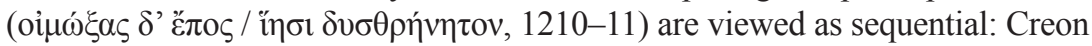
cries out and then speaks. Thus, Jebb translates: "he groaned and said in accents of anguish." 23 This translation also suggests that he interprets $\delta v \sigma \theta \rho \eta ́ v \eta \tau o v$ as expressive of the sound produced. This is possible, although in a limited way, as it is clear that the quotation is of Creon's spoken words, not a sung $\theta \rho \tilde{\eta} v o{ }^{24}{ }^{24}$ It may be instead that $\delta v \sigma \theta \rho \eta \dot{v} \eta$ ov describes only the content of the speech, as in Brown's translation: "he groaned and uttered words of bitter distress." 25

\section{Jebb (1888) 215.}

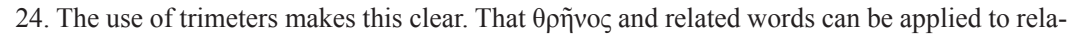

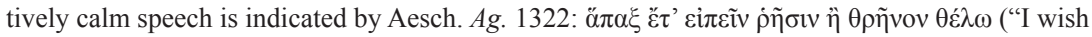
to make one more speech — or should I say lament"). Cassandra says she will speak ( $\varepsilon i \pi \varepsilon i v)$ her $\theta \rho \tilde{v} v o \varsigma$, and it follows in trimeters. As Fraenkel (1950) 616 observes, "now she is quite composed, she can and will speak once again."

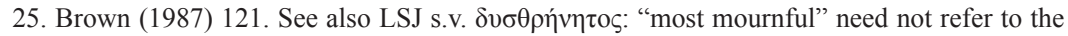
sound, although "loud wailing" clearly does. 


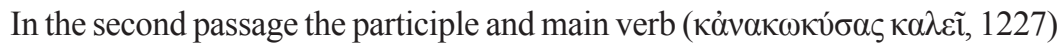
are frequently linked by scholars. For example, Griffith comments: “Kreon's short reported speech is . . . accompanied by further 'shrieks' or 'wails' (1227

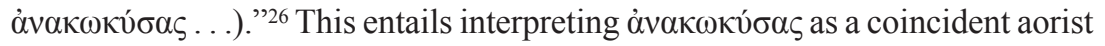
participle, used to modify the manner of the main verb. This is a plausible reading, but more commonly the aorist participle is used for actions that precede the main verb, and so this should be the default interpretation. ${ }^{27} \mathrm{I}$ am not convinced that the context provides enough grounds for a coincident reading. I argue below that the content of the quoted speech is fairly mild, so it hardly merits the use of $\alpha v \alpha \kappa \omega \kappa v \omega$. Furthermore, the number of times that a quoted speech is immediately preceded by a description of the speaker groaning or wailing suggests that this is a pattern the tragedians found effective, and so lends further weight

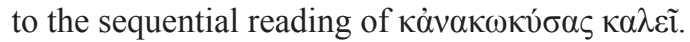

Turning to the speeches themselves, there is a certain degree of agitation to the words, as Griffith observes on 1211-18: "Enjambment, short paratactic or asyndetic sentences, exclamations, and rhetorical questions, all add to the sense of urgency, even panic." ${ }^{28}$ Many of these features are found in lines 1228-30 too,

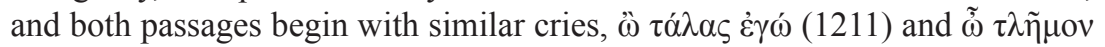
(1228), which are indicative of a heightened emotional state. ${ }^{29}$ For all that they convey the emotions of the speaker, staccato phrasing and rhetorical questions are coherent speech. ${ }^{30}$ Even the exclamations that begin these passages are proper language: $\tau \alpha \dot{\alpha} \lambda \alpha \varsigma$ and $\tau \lambda \eta \dot{\mu} \mu \nu$ are fully declinable adjectives. The $\tilde{\omega} / \tilde{\omega}$ probably functions merely as a vocative particle in $\tilde{\omega} \tau \lambda \tilde{\eta} \mu \circ v,{ }^{31}$ but even as an

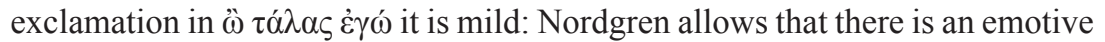
element to it, but says that $\omega^{\circ}$ "above all denotes the speaker's becoming aware of something." 32 This is very different to the extravagant non-linguistic cries that are common in emotional passages elsewhere in tragedy. ${ }^{33}$

26. Griffith (1999) 336. See also the translations of Jebb (1888) 217: "called to him with a voice of wailing," Brown (1987) 121: “called to him with a shriek," and Lloyd-Jones (1994-1996) 2.115: "with wailing accents called on him" (from which I have adapted the translation in the main text).

27. Van Emde Boas et al. (2019) 607-8 describe the uses of the aorist participle and the prevalence of the temporal meaning. See also Rijksbaron (2002) 122-26, who observes that in the temporal use the participle often precedes the main verb, as here.

28. Griffith (1999) 332.

29. McClure (1995) 45.

30. "Staccato phrasing" is Bers's terminology; he uses it (1997) 80 on HF 936-46. What I say about the passages I have quoted above might apply equally to this or other similar passages.

31. Typically, the vocative particle is written $\tilde{\omega}$ and the exclamation $\dddot{\omega}$, but according to LSJ (s.v. $\tilde{\omega}$ and $(\tilde{)})$ this is usual practice, not an absolute rule.

32. Nordgren (2015) 107.

33. For recent work discussing the prevalence of non-linguistic cries in tragedy see note 1. 
With the exception of $\ddot{\omega}$, it is rare for a passage of reported speech to include interjections, but oin ${ }^{\prime}$ or is found in two passages of Euripides:

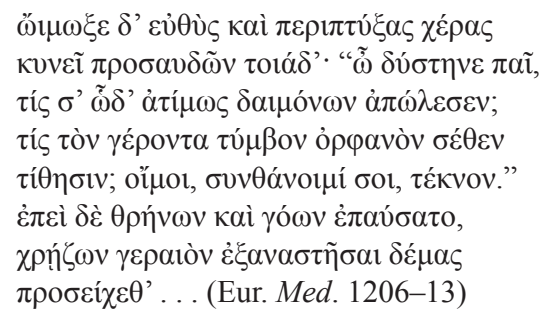

And at once he groaned aloud and, throwing his arms about her, kissed her and said, "O unhappy daughter, which of the gods has destroyed you so shamefully? Who has left me bereft of you, me, an old man at death's door? Oh, may I die with you, my daughter!" But when he had ceased from his wailing and lamenting and wanted to raise up his aged body, he was stuck fast...

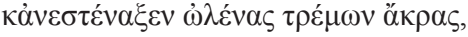

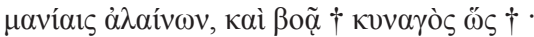

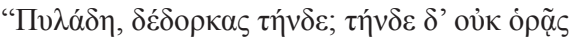

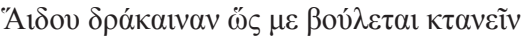

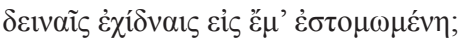

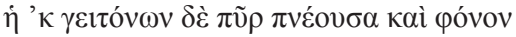

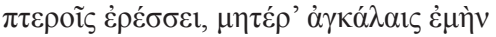

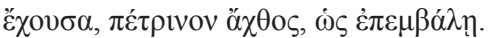
ớ̆

He groaned aloud, his hand trembled, and in his mad delirium he shouted, $\uparrow$ like a hunter $\uparrow$ : "Pylades, don't you see this one? Don't you see how this hellish dragon, fringed with terrible vipers, tries to kill me? And next to her another, breathing out fire and gore, beats her wings and holds my mother in her arms, a mass of stone, to hurl at me! Ah, she will kill me! Where can I escape to?"

Considering the verbs of speaking first, I note that these are two further passages

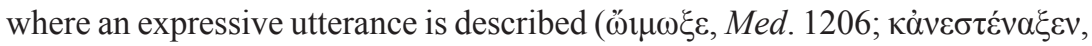
IT 283), before a milder verb introduces the direct speech ( Med. 1207; ßoõ , IT 284). The Medea passage also includes a capping phrase

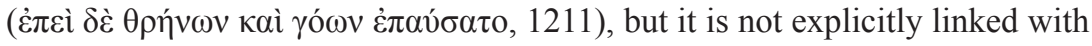
the reported speech, and it seems instead to mean that $\theta \rho \tilde{v} v o$ and $\gamma$ óot followed the quoted words. A Sophoclean parallel shows that this is a plausible reading. 
In Oedipus Coloneus, the Messenger ends his quotation of Oedipus's words to his children by saying:

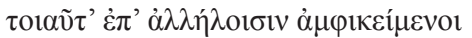

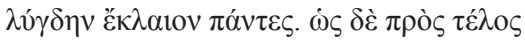

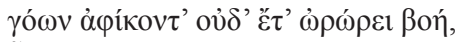

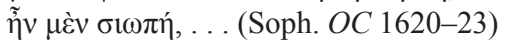

Thus, clinging closely to each other, all of them sobbed; but when they came to the end of their lamenting, and no sound still rose up, there was silence...

The verb of speaking in the capping phrase (ह̌ $\kappa \lambda \alpha 10 v)$ is third person, which makes it impossible to directly associate this verb with the speech we have just heard: Oedipus alone spoke the quoted words, but they all lamented. ${ }^{34}$ The

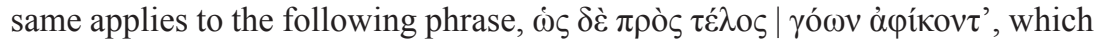

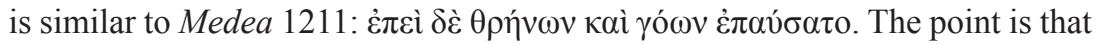
this type of capping phrase does not necessarily refer to what has just been quoted but can instead be a description of utterances that followed the quoted speech. This seems the preferable reading of the Medea passage, as otherwise we have to imagine that Creon embraced and mourned his daughter for only the time it took to utter the brief quoted speech before trying to stand up and finding he was stuck to her.

Turning to the content of these two Euripidean passages, the reported speeches here bear several of the hallmarks of emotional speech - short phrases, rhetorical questions - and the use of orf por must add to that impression. But the use of

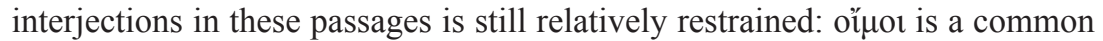
interjection in tragedy, appearing 190 times ${ }^{35}$ and in general appears to be one of the milder ones, connoting a broad range of emotions "from impatience and annoyance to despair and shock." ${ }^{36}$ The context in these passages means it must be taken as indicative of despair or grief, but it appears singly here, not in combination with $\mu$ ol or with an expression such as $\tau \alpha \dot{\lambda} \lambda \alpha \varsigma$, which might augment its emotional force somewhat. ${ }^{37}$

The form of these passages, their length and metrical shape, adds to the impression of restraint here. That the form of a passage contributes to its emotional

34. Markantonatos (2002) 143 notes the contrast between this striking capping phrase (he points out the use of $\lambda \hat{\gamma} \gamma \delta \eta v$, a hapax), which cannot be associated with the spoken words, and the "dispassionate introduction" ( $\varepsilon \tilde{i} \pi \varepsilon v, 1611)$.

35. Nordgren (2015) 108.

36. Nordgren (2015) 119.

37. Nordgren (2015) 114 observes the frequent coupling of oínot with "self-pitying expressions." 
intensity is widely acknowledged - lyric passages are often held to be more agitated than stichic ${ }^{38}$ — and the importance of form for quoted speech has already been noted by Bers, who says of Neoptolemus's false narratives in Sophocles's Philoctetes that "one might regard an unvarying full-trimeter length as archaic and stiff." ${ }^{39}$ That both these passages span several lines of full iambic trimeters, the meter of regular speech, suggests a certain degree of restraint. However, there is one incomplete trimeter in each passage, the first line in Medea and the last in Iphigenia among the Taurians. Quoted speech which starts mid-line is found in all three tragedians, but it is most common in later Euripides: in the first seven plays (up to Suppliants) there are six instances in 22 embedded speeches (27\%); in the remainder (from Electra) there are 33 instances in 59

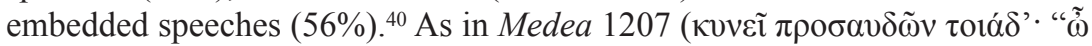
$\delta$ $\delta \tau \tau \eta v \varepsilon \pi \alpha \tilde{\imath}$ '), the first line is often comprised of a clause or phrase introducing the quoted speech, followed by the opening cry or address of the speech itself. Thus, the opening address in lines like this does sit outside a full trimeter line, which perhaps contributes in some degree to the sense of an exclamation.

Speeches that end mid-line are much more unusual, being completely absent in Aeschylus and Sophocles ${ }^{41}$ and only becoming common in later Euripides. In total 20 out of 81 quoted speeches in Euripides end mid-line, and they are particularly frequent in Helen, where they comprise five out of ten speeches. The first two instances are in Talthybius's speech in Hecuba, which means that according to conventional dating the first five extant plays of Euripides, or the first 14 passages of quoted speech, lack mid-line endings. If we hypothesize that Euripides was equally likely to end a quotation mid-line at any point in his career, then the probability of the first 14 embedded speeches all ending at a verse end would be $0.019 .{ }^{42}$ It is likely, then, that this hypothesis is incorrect

38. See, e.g., Barrett (1964) 319, who observes that at Eur. Hipp. 817-51, where dochmiacs alternate with pairs of iambic trimeters to depict Theseus's attempts to control his grief, "the poet relies more on meter (and delivery) than on language to bring out the effect he needs."

39. Bers (1997) 61.

40. For the analysis of trends in Euripides I use the dates in Collard (1981) 2. I leave out of account $C y c$. (as a satyr play), the fragmentary plays because of their uncertain dating, and Rhes. and $I A$ 1532-629 because of their uncertain authorship. There are no quoted speeches in my corpus from Eur. Tro. Sophocles starts quotations mid-line in six out of 19 passages, Aeschylus in one out of four (excluding $P V$ ). All percentages are rounded to zero decimal places.

41. I have found one instance outside my corpus of a mid-line ending in Aeschylus: Eum. 757-60, which is a hypothetical tis-speech and not part of an extended narrative.

42. On this hypothesis the probability of any quotation ending mid-line would be (20/81). Thus, the calculation to get the probability of an unbroken sequence of 14 quotations that do not end mid-line is $(61 / 81)^{14}$. I have rounded the result to three decimal places. 
and that the frequency of mid-line endings in Euripides's later plays represents a stylistic change on the dramatist's part, rather than being the result of random distribution. I do not suggest that mid-line endings are in themselves enormously effective, but merely that they are a small indication of a move towards a freer and less formal representation of direct speech in Euripides's later plays. ${ }^{43} \mathrm{How}-$

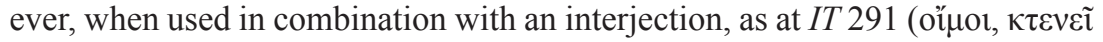
$\mu \varepsilon^{\cdot} \pi$ oĩ $\varphi v ́ \gamma \omega ;$ ), the mid-line ending may contribute to the sense of the cry going beyond the bounds of normal speech.

The loosening of these restraints becomes more pronounced in Euripides's Phoenissae, both in the form and in the verbs of speaking used. An embedded speech in the First Messenger's narrative is introduced, at line 1144, by a verb not normally used of human voices, but rather of animals, particularly birds

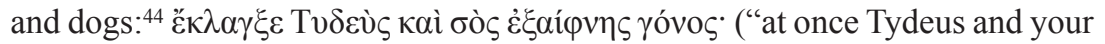
son shouted out"). By associating the speech here with the sound of animals Euripides hints at the extremes that Tydeus and Polyneices have reached, that their speech takes on inhuman tones. ${ }^{45}$ This word can also indicate something a bit harsher than a normal human shout, a "sharp piercing sound." ${ }^{6}$ And so, although there is nothing in the form or content of this passage which indicates expressive speech, this is the first properly evocative verb of speaking we find in extant tragedy, and it comes in one of Euripides's last plays. Just a few hundred lines later is the next instance, when the Second Messenger quotes first Jocasta's, and then Antigone's, words over the dying Eteocles and Polyneices:

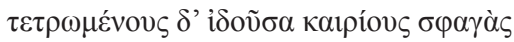

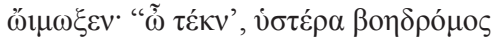

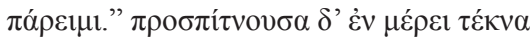

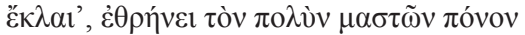

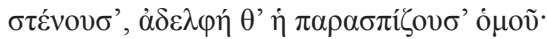

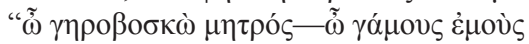

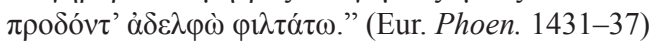

When she saw that they were mortally wounded, she cried out in pain, "O children, my help has come too late!" Falling on her sons in turn she wept and lamented, sighing for the lost effort of suckling them, and so did their

43. A further indication of this trend is the way Euripides starts to have his narrators interrupt the embedded speech, which first occurs at El. 788-89, then at HF 988, and finally at Phoen. 1452 (De Jong [1991] 201).

44. LSJ s.v. $\kappa \lambda \alpha ́ \zeta \omega$. See also Craik (1988) 236, who translates here "screamed" and says, "the verb is commonly applied to the cry of birds."

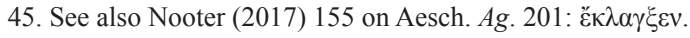

46. LSJ s.v. $\kappa \lambda \alpha ́ \zeta \omega$. 
sister, who accompanied her: "O support of your mother's old age! O dear brothers, who have not seen to my marriage."

There can be no doubt that $\ddot{\omega} \mu \omega \xi \varepsilon v$ conveys both the heightened emotional state of the speaker and suggests something expressive about the sound, above

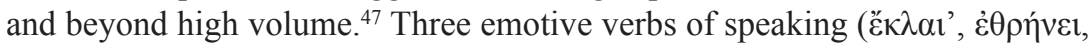
$\sigma \tau \varepsilon \dot{v} 0 v \sigma$ ') follow Jocasta's speech and cannot be associated with it, though there is a hint that these should apply to Antigone's speech in 1436-37, which itself lacks an explicit verb of speaking.

It is noticeable that at this moment of great emotion both speeches are brief: Jocasta's is just five words and a simple sentence, while Antigone's is not even a full clause, just an exclamation or address. Both speeches end mid-line, but Jocasta's also starts mid-line, and is so short that it contains no full trimeter. There are only a few other such speeches in tragedy, all in later Euripides: HF 975-76, IT 267-68, Hel. 1581 (just two words), 1603-04, Melanippe Captive, TrGF F 495.8-9 Kannicht).$^{48}$ Wilamowitz notes the force of this particular pattern (on $H F$ 975-76): "Die sich übersturzende Leidenschaftlichkeit der Handlung malt sich in ... dem Zerreissen des Verses, da vor dem letzten und nach dem ersten Fusse des folgendes interpungiert ist. ${ }^{\text {"49 }}$ I suspect it is no coincidence that one of the few speeches that is introduced with an evocative verb of speaking is also one of the few that contains no full trimeter line; both features are indicative of a move away from restraint in the presentation of direct speech that we find in later Euripides.

This trend reaches its apex in the Phrygian's speech in Orestes, which has many features of a messenger's speech, but is delivered in a lyric monody. This narrative contains four embedded speeches, but it culminates with Helen's brief

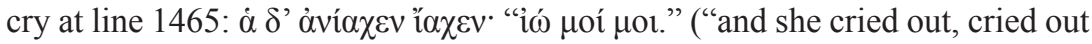
'Ah, ah me"'). The verb of speaking here, íx $\chi \omega$, indicates first and foremost a loud sound, but it is also commonly used for a "shriek in alarm or pain," ${ }^{50}$ and thus conveys a harsh and emotionally charged sound.

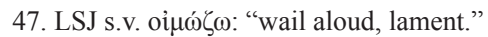

48. Cropp and Fick (1985) 83-84 date Melanippe Captive between 426 and 412, based on resolutions in the fragments. When they factor in the external evidence, they favour later within that range: "the best guess might be that both Melanippe plays were produced in the period 421-413." The presence of such metrical freedom in reported speech, which is otherwise unattested as early as the $420 \mathrm{~s}$, is a further piece of evidence to add to the scales in support of a date in the $410 \mathrm{~s}$. At Eur. Phaethon, $\operatorname{Tr} G F$ F 779.9-10 Kannicht (=176-77 in Diggle [1970]), the fragment itself ends mid-line, so it is possible the quotation continues beyond what has survived.

49. Wilamowitz-Moellendorf (1909) 424.

50. LSJ s.v. ió $\chi \omega$. See also West (1987) 159, who translates here "she screamed aloud, screamed." Gurd (2016) 34 emphasizes the violent aspects of the sound it describes in his discussion of ió $\chi \omega$ at Hes. Theog. 69. 
As part of a lyric passage this speech of course has a different form to most quoted speeches, but the meter does not dictate the content. Euripides has chosen for Helen's speech here to consist of an inarticulate cry (í́ $\mu$ oí $\mu \mathrm{or}$ ), quite unlike anything we find elsewhere in quoted speeches in tragedy. This is certainly the strongest interjection in quoted speech; Nordgren says of i tics are emotive and denote a sensation of grief, perhaps also including fear or anxiety." 51 The effect of $i \omega$ in our passage is strengthened by its combination with $\mu$ oí $\mu$ or. While i $\omega$ itself is very common in tragedy (appearing 223 times), ${ }^{52}$ in this combination it appears only 29 times. Some of the manuscripts include

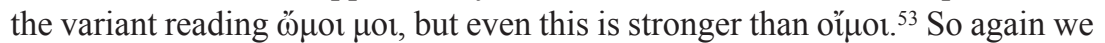
find that one of the few passages with an expressive introduction is also one of the few with particularly expressive content.

In Sophocles there is only one interjection, excepting $\dddot{\omega}$, in reported speech: o' $\mu \mathrm{ot}$ in the fragmentary tragedy Eurypylus:

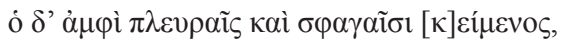

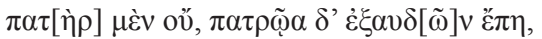

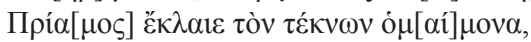

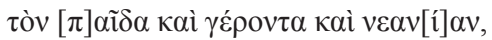

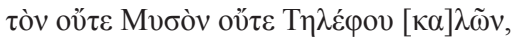

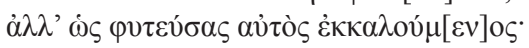
“oứ

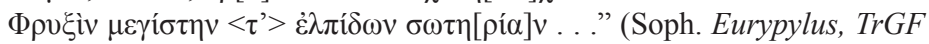
210.70-77 F Radt)

And Priam, lying upon his mangled body, though not his father spoke as though he were, weeping for the kinsman of his sons, at once boy and elder and young man, calling on him not as a Mysian nor as son of Telephus, but invoking him as though begotten by himself. "Ah, my son, I betrayed you, though I had in you the last and greatest hope of salvation for the Phrygians ..."

The quoted speech continues for at least four more lines, and the manuscript is so fragmentary that we do not have its ending. In respect of form, then, it

51. Nordgren (2015) 142. See also Biraud (2010) 136-37. Fraenkel (1950) 607, commenting on ì̀ $\pi \alpha ́ \tau \varepsilon \rho$ at Aesch. $\mathrm{Ag} .1305$, says it is "exceedingly strong . . . not a mere appeal but a shriek."

52. Nordgren (2015) 129.

53. Barrett (1964) 316 notes that $̋ \mu \mathrm{or}$ is the lyric equivalent of ol丷 $\mu$ o, which in itself suggests it is a stronger term, since lyrics tend to be more emotional than trimeters (see note 38, above). Note also that Page (1938) 178 prefers to read oǒ $\mu$ or at Eur. Med. 1371, because $̋ \mu$ or would be "too melodramatic." The duplication of $\mu \mathrm{o}$ in $\omega \mu \mathrm{o}$ $\mu \mathrm{o}$ strengthens the expression and makes it far rarer: Nordgren (2015) 108 counts 75 instances of $\omega \mu$ or, but I only find 15 of $\% \mu$ or $\mu$ or in tragedy. 
seems to be typical of Sophoclean quoted speeches, which tend to be fairly substantial (at least in comparison to late Euripides) when quoting characters at emotional moments: Trach. 797-802, 920-22, Ant. 1211-18, 1228-30, OC 1611-19. I note that oinor here appears at the head of the first line of quoted speech, and in its two appearances in Euripides, Med. 1210 and IT 291, it is in the last line of quoted speech. In these positions it could be seen as suggesting a transition between the coherent speech, which is quoted, and more extravagant cries, which are not..$^{54}$

But of particular interest here is the introduction, which is very extended and consists of four separate verbs of speaking: three participles ( $\dot{\varepsilon} \xi \alpha v \delta \tilde{\omega} v, \kappa \alpha \lambda \tilde{\omega} v$,

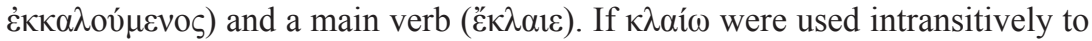
introduce direct speech it would be suggestive of violent sound, but the transitive use here seems to limit its relation to the quoted words somewhat, as LloydJones's translation (quoted above) suggests. ${ }^{55}$ The large distance (three lines) between $\tilde{\varepsilon} \kappa \lambda \alpha \_$and the quoted speech, together with the intervening participles

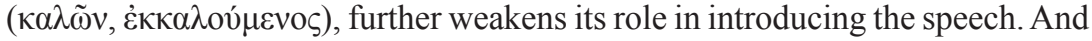
so, while the potential expressiveness of $\kappa \lambda \alpha i$ í should be acknowledged, this passage is another example of the way tragedians created a context for direct speech that was very expressive of sound, but rarely unambiguously characterized the sound of the direct speech itself.

Earlier in the same messenger speech ( $\operatorname{Tr} G F \mathrm{~F} 210.66$ Radt) there is another potentially expressive verb of speaking, where it seems likely, despite the frag-

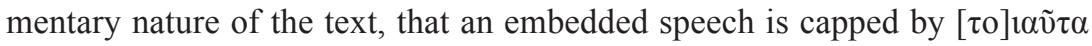

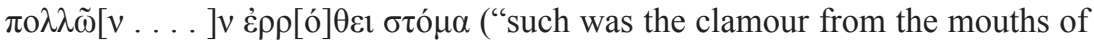
many"). As a verb of speaking $\dot{\rho} 0 \theta \dot{\varepsilon} \omega$ is unusual in that it may refer to any type of noise. It is used of human voices only here and in Sophocles's Antigone (twice: 259 and 290), though its cognates are sometimes used of speech. In all three places there are multiple speakers, and it seems to contain the idea of a mixed or confused sound. ${ }^{56}$ But other than that it does not appear to characterize the sound clearly, as Proc says of ṕó $\theta$ os: "it may be a shout, normal volume speech

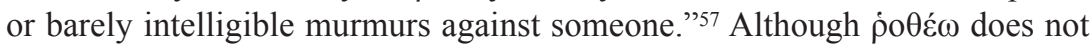
indicate particularly emotional or violent sounding speech, nevertheless it is an unusual verb of speaking, and it is interesting that it appears in close proximity

54. Note too that a description of such cries at Eur. Med. 1211 caps a passage of quoted speech. 55. Lloyd-Jones (1994-1996) vol. 3 93. Compare its use in Homer: $\kappa \lambda \alpha i \omega$ is used to introduce or cap direct speech 11 times in the second half of the Iliad, but always intransitively.

56. LSJ s.v. $\dot{\rho} 0 \theta \dot{\varepsilon} \omega$.

57. Proc (2012) 132, in an article whose main argument is that it is incorrect to read any sense of foreign or incoherent speech into jó $\theta$ os. 
to the passage discussed above, which itself has an extensive speech introduction and contains the most powerful interjection (ö $\mu \mathrm{or}$ ) in Sophoclean direct speech. ${ }^{58}$

In this section I have examined in detail the passages in my corpus that are the most expressive in terms of the direct speeches' description, content, or form. It is my claim that even in these passages there is a significant degree of restraint to the direct speeches. I have shown how in only three plays are the verbs used to describe the speeches indicative of a harsh or violent utterance, and this is all the more noticeable given the number of passages where the description of such an utterance closely precedes (or occasionally follows) the quoted speech. In some of these places the language is ambiguous, and I have been compelled to argue against the interpretations of earlier scholars, who prefer to take the expressive descriptions of sound as referring to the direct speech. In addition to these specific arguments, I note that, despite the range of different ways that the main verb is combined with more expressive descriptions, we never get any expressive description that unambiguously refers to the direct speech. So, we find expressive verbs as aorist participles, but never as present participles, nor do we find adverbs or datives of manner that characterize the sound. It is unlikely this pattern would emerge by chance, rather it seems that the tragedians, while trying to maintain a context that was evocative of sound, did not intend for the direct speech itself to be expressively characterized in these passages.

In their form and content, too, the quoted speeches do not, on the whole, appear particularly expressive. While the tragedians use a range of techniques to indicate agitation in quoted speeches, they rarely allow the utterance to descend to the point of pure interjections. Even on the three occasions where oif $\mu$ ot is used, it is always embedded in an extended and coherent thought. Direct speeches tend to cling closely to the trimeter form, which also suggests restrained speech. The convention of the formal messenger speech does not impose this restriction: the tragedians could have inserted extrametrical cries into a run of trimeters, and Euripides in his later plays found other ways of achieving metrical variety. It seems that, with a few exceptions, the tragedians deliberately avoided highly expressive embedded direct speech.

58. Our corpus of reported speech in Sophocles is too small to be able to draw firm conclusions, but the more emotive presentation may be because here the reporting figure is (presumably) a nonGreek, as is the quoted speaker (Priam for lines 76-81; the speakers of the speech capped at 65 are unknown, but likely to be non-Greek). Hall (1989) 83-84 has described the tendency for non-Greeks to be portrayed as more emotional. In Euripides too two of the three violent interjections in direct speech are quoted by non-Greek speakers (Eur. IT 291 and Or. 1465; the exception is Eur. Med. $1210)$, even though the majority of reporting figures are Greek. 


\section{Interpreting Restraint}

There remain the questions of why the patterns I have traced developed and how they impact our interpretation of the plays. For several of the passages I have discussed, a narratological approach offers a satisfying explanation of why the direct speech is presented in such a restrained way. Such an approach treats the reporting character as a narrator and focalizer, acknowledging that they select when and how to present the direct quotations and that they do so in a way that aligns with their preoccupations. ${ }^{59}$ Thus for Alcestis, Markantonatos explains Alcestis's servant's use of the unemotive $\lambda \dot{\varepsilon} \gamma \varepsilon 1$ (176) for the verb of speaking as part of the presentation of Alcestis as "surprisingly cool, calm, and collected in the present crisis." ${ }^{60}$ De Jong observes how the Messenger in Hippolytus is eager to present Hippolytus positively and as unjustly treated by Theseus, and this explains the Messenger's decision to quote at 1182-84 not Hippolytus's laments, but his resolution to obey his father regardless of the injustice. ${ }^{61}$ At Trachiniae 797-802 Hyllus's decision to quote not his father's groans of pain but rather the instructions directed towards himself can be explained as Hyllus choosing to quote the part most relevant to himself.

But there are also passages where it seems that direct quotation of more expressive utterances would accord with the reporting figure's preoccupations, and yet they are still avoided. I have described in the previous section how at Trachiniae 919-23 the report of Deianeira's appeal to her marriage bed is very similar to the report of Alcestis's appeal at Alcestis 175-82. However, unlike Alcestis's servant, Deianeira's nurse does not appear eager to stress her mistress' calmness, and this would hardly be appropriate: Deianeira has just discovered that she has caused her husband's imminent death and in this same moment of distress she goes on to kill herself. Why, then, are the verbs of speaking used not more expressive than $\check{\varepsilon} \lambda \varepsilon \xi \varepsilon v$ (920) and $\varphi \omega v \eta ́ \sigma \alpha \sigma \alpha(923)$ ? At Heracles 981 the Messenger describes a shout of victory that Heracles makes ( $\dot{\eta} \lambda \dot{\alpha} \lambda \alpha \xi \varepsilon)$, and De Jong is right that the use of this word adds to the horror of

59. De Jong (1991) 134. In addition to their own focalization, this character-narrator may also embed further layers of focalization, but, perhaps because of the nature of direct-speech introductions, I have found no conspicuous examples in my corpus. Markantonatos (2002) 139 argues

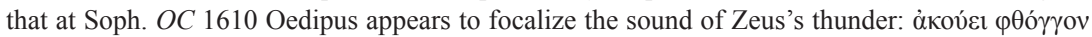

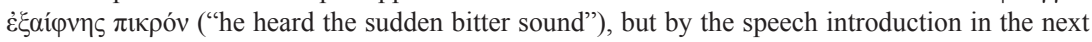
line I suspect he has relinquished focalization.

60. Markantonatos (2013) 48. Markantonatos (2002) 141 makes the same point about the Messenger's use of $\varepsilon \tilde{i} \pi \varepsilon v$ to introduce Oedipus's speech at Soph. OC 1611-19.

61. De Jong (1991) 137. See also Heath (1987) 156. 
Heracles boasting of his victory over one of his own sons. ${ }^{62}$ But surely this horror would have been enhanced even further if the Messenger had quoted the cry as well, rather than merely narrating it? Therefore, while explanations such as the ones given above, where the reporting figure's preoccupations are invoked, can be valid, the avoidance of expressive presentation of direct speech is so widespread that a further explanation is required. Perhaps the reason is simply that while it is natural for a character at the extremes of emotion to cry out themselves, it is less natural for an observer to repeat these cries when reporting their speech. ${ }^{63}$ The conventions of tragedy do not require strict naturalism, of course, and messenger speeches and other narratives in themselves are a rather un-naturalistic convention. But that does not mean that naturalism was never a consideration, and this would be another way that messengers and other anonymous figures are treated as characters, rather than mere functional devices.

In my view the delivery of quoted speeches in their original performances reflected the pattern of restraint that I have traced. Any attempt to reconstruct the delivery of a passage from the text is bound to be speculative and subjective, but a restrained delivery seems more probable..$^{64}$ The large number of interjections written in our manuscripts makes it less likely that shrieks or wails not represented in the text were performed, and the mild diction that we therefore find in passages of quoted speech, together with their restrained descriptions, strongly suggests a restrained delivery ${ }^{65}$ I see no reason why this should make the tragedies any less effective. It is clear that tragedy operates on a range of different emotional registers, and it is plausible that reserving the highest

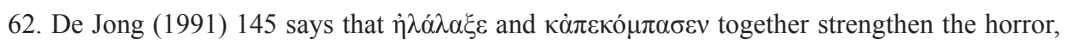

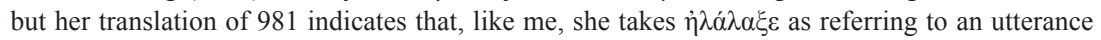
before the quoted words.

63. This would account for the frequency with which mild quoted speech is preceded or followed by descriptions of harsh sounds: it is not that the tragedian or reporter wants to suppress that these vocalizations occurred, it is rather that they are not suitable for quotation.

64. Wright (2019) 37-45 makes a robust case for a more open-ended approach to questions of staging, but such an approach should not treat all potential stagings as equally likely. Besides, his focus is on the visual aspects of staging, and the evidence for the vocal side is much more substantial.

65. By contrast, some scholars, e.g., Bers (1997) 75 and Griffith (1999) 336, seem to imply that shrieks were performed for specific passages. More generally, my claim for restrained delivery perhaps suggests that the tragedians were less concerned with making the messenger speech a vehicle for histrionic performance than Dickin (2009) claims, though I acknowledge that the absence of shrieks and wails in direct speech does not prevent the actors showcasing their talents in other ways. 
registers - shrieks and wails - for the actual characters who suffer would enhance the overall effect. ${ }^{66}$

However, I have also traced a discernible, though by no means consistent, ${ }^{67}$ pattern of restraints being loosened in the later stages of Euripides's career. It is plausible that this is linked to the way that the appeal of a reporting figure for both audience and actors seems to have grown from the late fifth century onwards. ${ }^{68}$ It is interesting to compare this with other developments in Euripidean tragedy. For example, Csapo has shown how, under the influence of New Music, the proportion of song delivered by actors increased throughout Euripides's life, and this pattern reflects the loosening of restraints in reported direct speech. ${ }^{69}$ Both trends culminate, and collide, in Orestes, where the Phrygian's narrative is delivered in a monody. It is perhaps no surprise that the most expressive direct speech in my corpus is in a non-Greek's song, ${ }^{70}$ but it is also possible more generally that some of the considerations that appear to have driven the increase in actors' song - the professionalization of acting, the increased interest in mimetic effects ${ }^{71}$ - were also responsible for the more expressive direct speech we find in late Euripides. ${ }^{72}$

\section{Appendix}

The table below lists all the reported speeches in my corpus. Plays of uncertain authorship are listed under authors to whom they are attributed for convenience only, and this should not be taken to imply any judgement about their authenticity.

66. Barlow (2008) 77 expresses something similar, but her focus is more on the need for the narrative to get across the facts that allow the suffering to be understood.

67. The quoted speeches in Eur. Ion are unremarkable, for instance.

68. See Green (1999), on the evidence of vase-paintings, and Kaimio (1993) 28-31. See also Dickin (2009), who distinguishes less between late Euripides and other extant tragedy.

69. Notwithstanding a few anomalies, the pattern Csapo (1999-2000) 402-3 traces is clear: a steady rise until $O r$., followed by a noticeable decrease for $I A$ and $B a c c h$. Restraint in direct speech is more subjective, but I note an increase in metrical variety in the $410 \mathrm{~s}$, the introduction of expressive verbs of speaking in Phoen., and the culmination of the trend with Helen's cry at Or. 1465; the direct speech in $I A$ and Bacch., however, is unremarkable.

70. Hall (1989) 83-84 describes how "unrestrained emotionalism" was frequently associated with non-Greeks in tragedy. For the link between song and emotionalism see note 38 .

71. Csapo (1999-2000). There may well be other factors behind the increase in monody in late Euripides; Catenaccio (2017) 2 identifies several uses to which it is put: "to shape plot, to display states of heightened emotion, and to develop character."

72. I would like to thank the ICS anonymous reader for their helpful comments. 


\begin{tabular}{|c|c|c|}
\hline \multirow[t]{5}{*}{ Aeschylus } & Persians & $402-05$ \\
\hline & Seven against Thebes & $580-89$ \\
\hline & Agamemnon & $577-79$ \\
\hline & Libation Bearers & $680-87$ \\
\hline & Prometheus Bound & $647-54$ \\
\hline \multirow[t]{6}{*}{ Sophocles } & Trachiniae & $797-802,920-22$ \\
\hline & Ajax & $288-91,293,764-65,767-69,774-75$ \\
\hline & Antigone & $228-30,1211-18,1228-30$ \\
\hline & Philoctetes & $364-66,369-70,372-73,379-81$ \\
\hline & Oedipus Coloneus & $1611-19,1627-28,1631-35,1640-44$ \\
\hline & Eurypylus & $\operatorname{Tr} G F$ F $210.65,210.76-81$ Radt \\
\hline \multirow[t]{23}{*}{ Euripides } & Alcestis & $163-69,177-82$ \\
\hline & Medea & $1151-55,1207-10$ \\
\hline & Heraclidae & $804-10,826-27,839-40$ \\
\hline & Hippolytus & $1182-84,1191-93,1240-42$ \\
\hline & Andromache & $1092-95,1104-05,1106-8,1125-26$ \\
\hline & Hecuba & $532-33,534-41,547-52,563-65,577-80$ \\
\hline & Suppliants & $669-72,702,711-12$ \\
\hline & Electra & $\begin{array}{l}779-80,781-82,784-89,791-92,793-96,805- \\
07,815-18,831,831-33,834-37,847-51\end{array}$ \\
\hline & Heracles & $936-46,952,965-67,975-76,982-83,988-89$ \\
\hline & Iphigenia among the Taurians & $\begin{array}{l}267-68,270-74,285-91,321-22,1358-60 \\
1361-63,1386-89,1398-1402\end{array}$ \\
\hline & Ion & $29-36,1128-31,1178-80,1210-12,1220-21$ \\
\hline & Helen & $\begin{array}{l}608-15,1543-46,1560-64,1579-80,1581 \\
1584-87,1589-91,1593-95,1597-99,1603-04\end{array}$ \\
\hline & Phoenissae & $\begin{array}{l}1145-47,1225-35,1250-51,1252-53,1365-68 \\
1373-76,1432-33,1436-37,1444-53\end{array}$ \\
\hline & Orestes & $\begin{array}{l}875-76,877-78,885-87,932-42,1439-43,1447 \\
1461-64,1465\end{array}$ \\
\hline & Bacchae & $\begin{array}{l}718-21,731-33,1059-62,1079-81,1106-09 \\
1118-21\end{array}$ \\
\hline & Iphigenia at Aulis & $1552-60,1570-76,1591-1601$ \\
\hline & Rhesus & $298-99$ \\
\hline & Cyclops & $413-15,418-19$ \\
\hline & Archelaus & $\operatorname{Tr} G F$ F 228a.23-25 Kannicht \\
\hline & Melanippe Captive & $\operatorname{Tr} G F$ F 495.1, 495.8-9, 495.15-17 Kannicht \\
\hline & Stheneboea & $\operatorname{Tr} G F$ F 661.12-14, 664.2 Kannicht \\
\hline & Phaethon & $\operatorname{Tr} G F$ F 779.1-4, 9-10 Kannicht \\
\hline & Sisyphus & $\operatorname{Tr} G F$ F 43, 19.22-24 Snell \\
\hline
\end{tabular}

\section{Independent Scholar}

jamesclark545@gmail.com

\section{Works Cited}

Allan, R. J. 2009. "Towards a Typology of the Narrative Modes in Ancient Greek: Text Types and Narrative Structure in Euripidean Messenger Speeches." In S. Wakker and G. Bakker, eds., Discourse Cohesion in Ancient Greek, 171-204. Leiden: Brill. 
Barrett, J. 2002. Staged Narrative: Poetics and the Messenger in Greek Tragedy. Berkeley: University of California Press.

Barrett, W. S., ed. 1964. Euripides: Hippolytus. Oxford: Clarendon Press.

Barlow, S. 2008. The Imagery of Euripides. 3rd ed. London: Bristol Classical Press.

Bers, V. 1997. Speech in Speech: Studies in Incorporated Oratio Recta in Attic Drama and Oratory. Lanham, MD: Rowman \& Littlefield.

Biraud, M. 2010. Les Interjections du théâtre grec antique: Étude sémantique et pragmatique. Louvain-la-Neuve: Peeters.

Brown, A., ed. 1987. Sophocles: Antigone. Warminster: Aris \& Phillips.

Catenaccio, C. 2017. Monody and Dramatic Form in Late Euripides. Ph.D. diss., Columbia University. https://doi.org/10.7916/D8G44X64

Collard, C. 1981. Euripides. Oxford: Clarendon Press.

Conacher, D. J., ed. 1988. Euripides: Alcestis. Warminster: Aris \& Phillips.

Craik, E., ed. 1988. Euripides: Phoenician Women. Warminster: Aris \& Phillips.

Cropp, M., and G. Fick. 1985. Resolution and Chronology in Euripides: The Fragmentary Tragedies. BICS Supp. 43. London: Institute of Classical Studies.

Csapo, E. 1999-2000. “Later Euripidean Music.” In M. Cropp, K. Lee, and D. Sansone, eds., Euripides and Tragic Theatre in the Late Fifth Century, ICS 24-25: 399-426.

De Jong, I. F. 1991. Narrative in Drama: The Art of the Euripidean Messenger-Speech. Leiden: Brill.

. 2004. Narrators and Focalizers: The Presentation of the Story in the Iliad, 2nd ed. London: Bristol Classical Press.

Dickin, M. 2009. A Vehicle for Performance: Acting the Messenger in Greek Tragedy. Lanham, MD: University Press of America.

Diggle, J., ed. 1970. Euripides: Phaethon. Cambridge: Cambridge University Press.

— ed. 1981-1994. Euripidis Fabulae. Oxford: Clarendon Press.

Dindorf, W., ed. 1859. Sophoclis tragoediae, 3rd ed. Leipzig: Teubner.

Easterling, P. E., ed. 1982. Sophocles: Trachiniae. Cambridge: Cambridge University Press.

Fraenkel, E., ed. 1950. Aeschylus: Agamemnon. Oxford: Clarendon Press.

Garvie, A. F., ed. 2009. Aeschylus: Persae. Oxford: Oxford University Press.

Green, J. R. 1999. "Tragedy and the Spectacle of the Mind: Messenger Speeches, Actors, Narrative, and Audience Imagination in Fourth-Century BCE Vase Painting." In B. Bergmann and C. Kondoleon, eds., The Art of the Ancient Spectacle, 37-64. Washington: Yale University Press.

Griffith, M., ed. 1999. Sophocles: Antigone. Cambridge: Cambridge University Press.

Gurd, S. 2013. "Resonance: Aeschylus' Persae and the Poetics of Sound." Ramus 42.1-2: 122-37.

-2016. Dissonance: Auditory Aesthetics in Ancient Greece. New York: Fordham University Press.

Hall, E. 1989. Inventing the Barbarian: Greek Self-Definition through Tragedy. Oxford: Clarendon Press.

Heath, M. 1987. The Poetics of Greek Tragedy. London: Duckworth. 
Jebb, R. C., ed. 1888. Sophocles: Antigone. Cambridge: Cambridge University Press. Kaimio, M. 1977. Characterization of Sound in Early Greek Literature. Helsinki: Societas Scientarum Fennica.

. 1993. "The Protagonist in Greek Tragedy." Arctos 27: 19-33.

Kovacs, D. M., ed. 1994-2002. Euripides. Cambridge, MA: Harvard University Press. - 2014. "The End of Sophocles' Oedipus Tyrannus: The Sceptical Case Restated." JHS 134: 56-65.

Levinson, S. C. 1983. Pragmatics. Cambridge: Cambridge University Press.

Lloyd-Jones, H., ed. 1994-1996. Sophocles. Cambridge, MA: Harvard University Press. Lloyd-Jones, H., and N. G. Wilson. 1992. Sophoclis Fabulae. Oxford: Clarendon Press.

Markantonatos, A. 2002. Tragic Narrative: A Narratological Study of Sophocles' Oedipus at Colonus. Berlin: De Gruyter.

- 2013. Euripides'Alcestis: Narrative, Myth, and Religion. Berlin: De Gruyter.

McClure, L. 1995. "Female Speech and Characterization in Euripides." In F. De Martino and A. H. Sommerstein, eds., Lo Spettacolo delle voci, vol. 2, 35-60. Bari: Levante.

Nooter, S. 2017. The Mortal Voice in the Tragedies of Aeschylus. Cambridge: Cambridge University Press.

Nordgren, L. 2015. Greek Interjections: Syntax, Semantics and Pragmatics. Berlin: De Gruyter.

Page, D. L., ed. 1938. Euripides: Medea. Oxford: Clarendon Press.

1972. Aeschyli Septem quae Supersunt Tragoedias. Oxford: Clarendon Press.

Perris, S. 2011. "What Maketh the Messenger: Reportage in Greek Tragedy." In A. Mackay, ed., ASCS 32: Selected Proceedings. www.ascs.org.au/news/ascs32/Perris.pdf

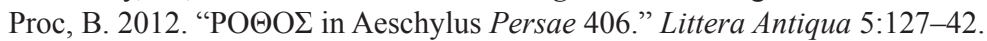

Radt, S., ed. 1999. Tragicorum Graecorum Fragmenta. Vol. IV, Sophocles. Göttingen: Vandenhoeck and Ruprecht.

Rijksbaron, A. 2002. The Syntax and Semantics of the Verb in Classical Greek: An Introduction. 3rd ed. Amsterdam: Gieben.

2006. "On False Historic Presents in Sophocles (and Euripides)." In I. J. F. De Jong and A. Rijksbaron, eds., Sophocles and the Greek Language: Aspects of Diction, Syntax, Pragmatics, 127-49. Leiden: Brill.

Sommerstein, A. H. ed. 2008. Aeschylus. Cambridge, MA: Harvard University Press.

Van Emde Boas, E. et al. 2019. Cambridge Grammar of Classical Greek. Cambridge: Cambridge University Press.

Weiss, N. 2017. "Noise, Music, Speech: The Representation of Lament in Greek Tragedy." AJPh 138: 243-66.

West, M. L., ed. 1987. Euripides: Orestes. Warminster: Aris \& Phillips.

Wilamowitz-Moellendorf, U. von, ed. 1909. Euripides: Herakles. 2nd ed. Berlin: Weidmann.

Wright, M. 2019. The Lost Plays of Greek Tragedy. Vol. 2: Aeschylus, Sophocles, and Euripides. London: Bloomsbury. 